\title{
Die ontwikkeling van 'n korrosiebestande langpadlengte-infrarooisel Deel I: Konstruksieparameters en -oorwegings
}

\author{
D.J. Delport en J.H. Potgieter* \\ Department Chemiese \& Metallurgiese Ingenieurswese, Technikon Pretoria, Privaat sak X680, Pretoria, 0001
}

W.G. Augustyn

Department Chemie \& Fisika, Technikon Pretoria, Technikon Pretoria, Privaat sak X680, Pretoria, 0001

J.H. Prior

Necsa, Posbus 582, Pretoria, 0001

\section{UITTREKSEL}

Hierdie artikel beskryf die konstruksie van 'n langpadlengte-infrarooisel wat gebruik kan word om korrosiewe gasmengsels kwalitatief en kwantitatief te analiseer. Die vereistes waaraan so 'n sel moet voldoen, word kortliks bespreek en die ontwerp word beskryf met spesifieke verwysing na geskikte materiale vir die spieël, die optimisering van die padlengte en die bepaling van die maksimum seinversterking. Na bepaling van die nodige ontwerpparameters, is dit uit vlekvrye staal gekonstrueer en in bedryf gestel.

\begin{abstract}
The development of a corrosion resistant long pathlength infrared cell Part I: Construction parameters and considerations

This paper describes the construction of a long pathlength infrared cell that is suitable for the qualitative and quantitative analyses of corrosive gas mixtures. The requirements of such a cell are discussed briefly and its design is described with specific reference to suitable materials for the mirror, the optimisation of the pathlength and to determining the maximum gain. After establishing the necessary design parameters, the cell was constructed from stainless steel and commissioned for practical applications.
\end{abstract}

\section{INLEIDING}

Langpadlengte-infrarooiselle kan vir 'n verskeidenheid doeleindes aangewend word. Gewilde toepassings sluit in die monitering van kontaminante in gevalle van lugbesoedeling ${ }^{1-6}$ en die meting van onsuiwerhede in kommersiële gasse. ${ }^{1,6-8}$ Hierdie tipe selle is gewoonlik nie geskik in gevalle waar korrosie kan plaasvind op die multiweerkaatsingspieëls en die glaswande van die sel nie.

Vir die konstruksie van sodanige sel, moet o.a. aan die volgende basiese vereistes voldoen word:

1) Die sel moet bestand wees teen korrosiewe gasse.

2) Dit moet geskik wees om baie lae konsentrasievlakke, tipies in die dpm- (dele-per-miljoen-) gebied van onsuiwerhede, te meet.

3) Dit moet geskik wees vir koppeling aan 'n kommersiële FT-IR-spektrofotometer, wat vir laboratorium- sowel as nywerheidsmetings benut kan word,

4) Die energie van die infrarooistraal moet so min as moontlik met veelvoudige spieëlweerkaatsings verlaag word.

5) Die weerkaatsingslagie van die spieël moet korrosiebestand wees.

6) Die konstruksie moet van so aard wees dat herstel en instandhouding van die sel maklik uitvoerbaar is.

7) Die optika, langpadlengtesel en detektor moet in een lugdigte houer wees wat met stikstof $\left(\mathrm{N}_{2}\right)$ gespoel kan word, sodat 'n vog- en koolstofdioksiedvrye spektrum verkry kan word.

Ten einde aan bostaande vereistes te voldoen, is besluit dat die sel slegs een spieël, naamlik die rompspieël, moet bevat wat met die gasse in kontak sal kom. Hierdie artikel beskryf die ontwerp en optimisering van die gekonstrueerde langpadlengte-infrarooisel.

\section{ONTWERP EN MATERIAALVEREISTES}

Die basiese ontwerp van die langpadlengte sel word in figuur 1 aangetoon. Die langpadlengte-gassel is op 'n toetsmonteerplaat bo-op 'n BOMEM 100 FT-IR-spektrofotometer gemonteer. Dit is so geplaas dat die infrarooibundel die spektrofotometer vertikaal verlaat deur 'n opening in die plaat en deur die padlengtebepalende spieël horisontaal in die langpadlengtesel in gereflekteer word, soos in figuur 1 aangetoon. Die verwysingspieël (goud) tesame met die reflektore se enkelstraalagtergrond word geneem. Daarna word die toetsrompspieël in die plek van die verwysingspieël geplaas en 'n enkelstraaltransmissiespektrum word opgeneem. Die twee enkelstraalspektra word nou van mekaar afgetrek, sodat slegs die transmissiespektrum van die toetsspieël verkry word.

Om korrosiebestandheid van die rompspieël te verseker, is besluit om dit met goud of titaannitried (TiN) te bedek. In die eerste poging is koper as basismateriaal vir die rompspieël gebruik en goud is d.m.v. 'n vakuumopdampproses op die oppervlakte gedeponeer. ${ }^{9}$ Goeie weerkaatsingseienskappe is aanvanklik met hierdie spieël verkry. Nadat korrosiewe gasse soos $\mathrm{UF}_{6}$ en HF gebruik is, is gevind dat die oppervlak van die goudspieël begin verdof het weens korrosie wat by die tussenvlak van die goud en koper plaasgevind het. Hierdie korrosie is toegeskryf aan moontlike swak hegting tussen die goud en koper en waarskynlike porositeit in die goudlagie. Die gevolglike "goudskileffek" wat waargeneem is a.g.v. korrosie, stem ooreen met soortgelyke waarnemings deur vroeëre werkers. ${ }^{10}$

Daar is vervolgens besluit om eerder vlekvrye staal as basismateriaal vir die rompspieël te gebruik. Goud is soos vantevore daarop aangebring, terwyl titaannitried met 'n holkatode-ontladingsgeweer daarop ioongeplateer is. ${ }^{9}$ Die 
weerkaatsingsvermoë van albei spieëls is gemeet en word in figuur 2 aangetoon. Die resolusie in albei gevalle was 'n kwartgolfgetal.

Goudbedekkings op die rompspieël het 'n gemiddeld van 99\% refleksie-energie oor die gemete golflengtegebied gelewer, terwyl TiN-bedekkings 'n laer weerkaatsingsvermoë gehad het en slegs 'n gemiddelde waarde van $92 \%$ refleksieenergie oor die golfgebied van $4000 \mathrm{~cm}^{-1}$ tot $500 \mathrm{~cm}^{-1}$ gelewer het. Daar is egter gevind dat TiN 'n uitsonderlike korrosiebestandheid vertoon het teen korrosiewe gasse en goud ver oortref het op hierdie gebied. Dit het byvoorbeeld geen noemenswaardige korrosie ondergaan na blootstelling aan $\mathrm{UF}_{6}$ vir 5 dae nie, en selfs in een van die mees korrosiewe gasmengsels bestaande uit lug en HF, het dit eers na 65 uur verwering begin toon.

\section{Bepaling van die optimum padlengte}

'n Reeks sferiese fokuspuntspieëls met fokuspunte van 1.04, $1.82,5.00$ en 4.07 is getoets om die beste sein-tot-ruisverhouding vir verskillende padlengtes te bepaal.

Die seinversterking ("gain") van elke spieël is gebruik om die langste padlengte vir elke spieël te verkry. Die seinversterking van 'n spieël word gedefinieer as die ruisvlakverhouding van die spieël by ' $n$ spesifieke padlengte tot die ruisvlak verkry met 'n standaard $100 \mathrm{~mm}$-sel. Die ruisvlak (in absorbansie-eenhede) van 'n spektrum word gedefinieer as die gemiddelde ruispiekhoogte (I) minus die ruispiekbasis $\left(\mathrm{I}_{\mathrm{o}}\right)$ oor 'n gedefinieerde golfgebied. In hierdie geval is die gebied 1300 $\mathrm{cm}^{-1}$ tot $900 \mathrm{~cm}^{-1}$ gekies. Wanneer 'n blanko bepaling in hierdie gebied gedoen is, het atmosferiese $\mathrm{CO}_{2}$ - en $\mathrm{H}_{2} \mathrm{O}$-absorbansiepieke geen invloed nie, omdat geeneen van hierdie spesies by hierdie golflengtegebied infrarooi-energie absorbeer nie.

Die seinversterking van elke spieël by verskillende padlengtes is vir 100 aftastings d.m.v. die volgende vergelyking bereken:

Seinversterking $($ vir 100 aftastings $)=$

$$
\left(\mathrm{P}_{\mathrm{n}} / \mathrm{P}_{\mathrm{o}}\right) *\left(\mathrm{G}_{\mathrm{o}} / \mathrm{G}_{\mathrm{n}}\right) \text { waar }
$$

$\mathrm{P}_{\mathrm{n}}=$ padlengte (in $\mathrm{m}$ ) wat getoets word

$\mathrm{P}_{\mathrm{o}}^{\mathrm{n}} \quad=100 \mathrm{~mm}$ (padlengte van die verwysingsel)
$\mathrm{G}_{\mathrm{o}}=$ ruisvlak van die instrument met $100 \mathrm{~mm}$ - verwysingsel
$\mathrm{G}_{\mathrm{n}}=$ ruisvlak van die instrument met die toetssel

Die seinversterking van elke padlengte in verhouding tot die standaard $100 \mathrm{~mm}$-verwysingsel is bereken deur die TiN-bedekte spieël op verskillende afstande (padlengtes) weg van die fokusserende spieël te plaas en dan vir elke padlengte die ruisvlak te meet. Grafieke van seinversterking teen padlengte is vir elke padlengtebepalende spieël opgestel en gebruik om die beste spieëlseinversterking vir die langste padlengte van elke spieël te bepaal.

Tabel 1 toon die seinversterking vir verskillende lengte fokuspuntspieëls as 'n funksie van die padlengte.

Tabel 1 toon dat die maksimum seinversterking vir 'n 1.04 m-fokuspuntspieël 17.88 keer groter is by $1.75 \mathrm{~m}$ as wat met 'n standaard $100 \mathrm{~mm}$-padlengtesel verkry word. Die beste spieël vir die optimum padlengte is gekies deur die grootste seinversterking vir die kortste padlengte as kriterium te gebruik. Die data in tabel 1 toon duidelik dat die $1.04 \mathrm{~m}$-fokuspuntspieël die voorkeurkeuse in hierdie geval is. Die $1.04 \mathrm{~m}$-fokuspuntspieël is dus vir die ontwikkeling van die langpadlengtesel gekies en het 'n padlengte van $1.75 \mathrm{~m}$ gelewer.

\section{Bepaling van die optimum getal aftastings}

Om die beste seinversterking van die sel te verkry, moes die minimum aantal aftastings vir die laagste ruisvlak bepaal word. Die langpadlengtesel vertoon 'n groter ruisvlakwaarde as die standaard $100 \mathrm{~mm}$-infrarooigassel a.g.v. energieverliese te wyte aan spieëlweerkaatsings en dik AgBr-infrarooivensters in die vensterblok (sien konstruksie in figuur 1). Om die sein-totruisverhouding te verbeter, is dit gevolglik nodig om meer aftastings te doen.

'n Reeks aftastings is in die golfgebied $1300 \mathrm{~cm}^{-1}$ tot 900 $\mathrm{cm}^{-1}$ uitgevoer en die ruisvlak is vir elke getal aftastings bepaal. Die resultate word in tabel 2 weergegee.

Dit blyk duidelik uit die waardes wat in tabel 2 weergegee word dat geen verdere seinversterking na 150 aftastings verkry word nie. Daar is bevind dat ongeveer agt minute benodig word om 150 aftastings te voltooi.

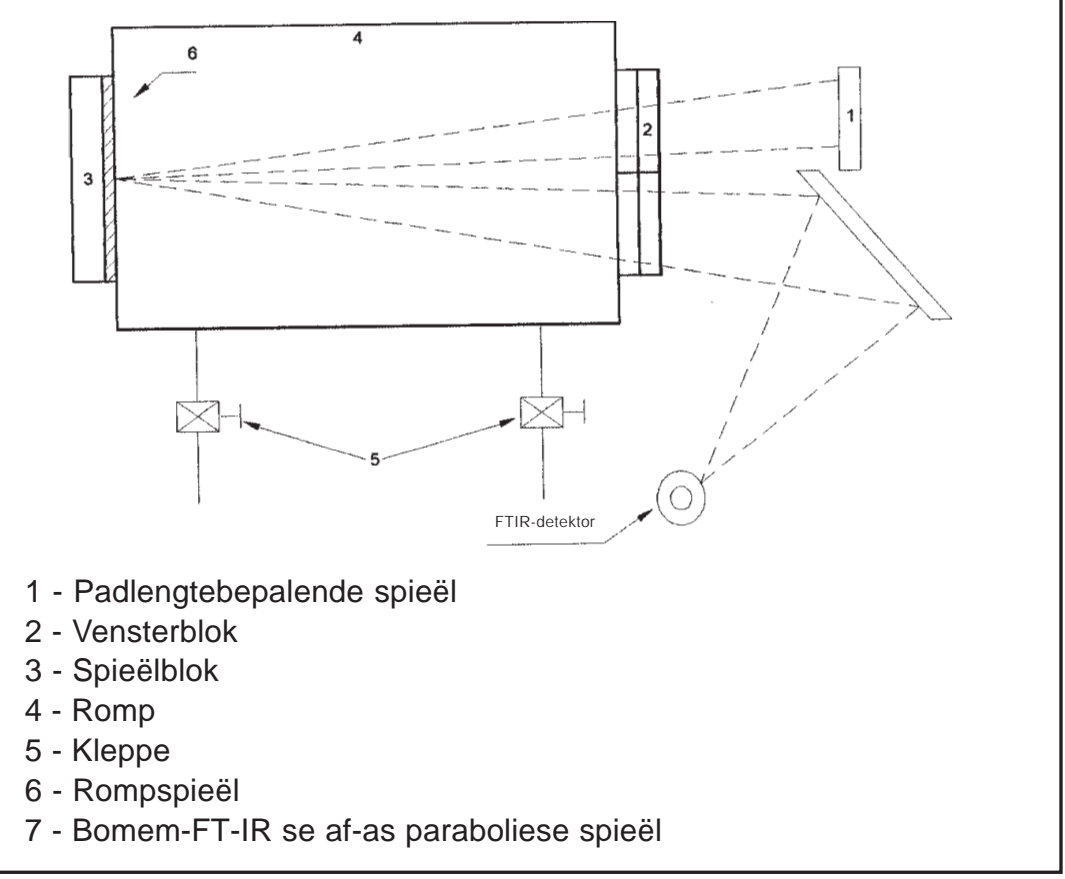

Figuur 1 Basiese ontwerp van langpadlengte-infrarooisel. 


\section{GEVOLGTREKKING}

Die ondersoek het tot die konstruksie van 'n 1.75 mlangpadlangte-infrarooisel vir die analise van gasmengsels gelei. Die sel is uit tipe 316 vlekvrye staal vervaardig en met 'n TiNioongeplateerde spieël voorsien om korrosiebestand te wees, selfs teen uiters chemies aggressiewe verbindings soos $\mathrm{UF}_{6}$ en HF. Die optimum padlengte van $1.75 \mathrm{~m}$ is bepaal deur 'n reeks fokuspuntspieëls te toets. Die optimum getal aftastings en aftastingstyd is bepaal om die minimum ruisvlak tydens metings te lewer. Die kalibrasie van die gekonstrueerde langpadlengtesel ten einde kwantitatiewe metings uit te voer, sal in 'n volgende publikasie bespreek word.
Tabel 2 Ruisvlak as 'n funksie van getal aftastings vir 'n 1.75 m-langpadlengte-infrarooisel

\begin{tabular}{|c|c|}
\hline AFTASTINGS & $\begin{array}{c}\text { GEMIDDELDE RUISVLAK } \\
\text { (ABSORBANSIE-EENHEDE) }\end{array}$ \\
\hline 10 & 0.00450 \\
\hline 50 & 0.00170 \\
\hline 100 & 0.00088 \\
\hline 150 & 0.0069 \\
\hline 200 & 0.0069 \\
\hline 300 & 0.0069 \\
\hline
\end{tabular}

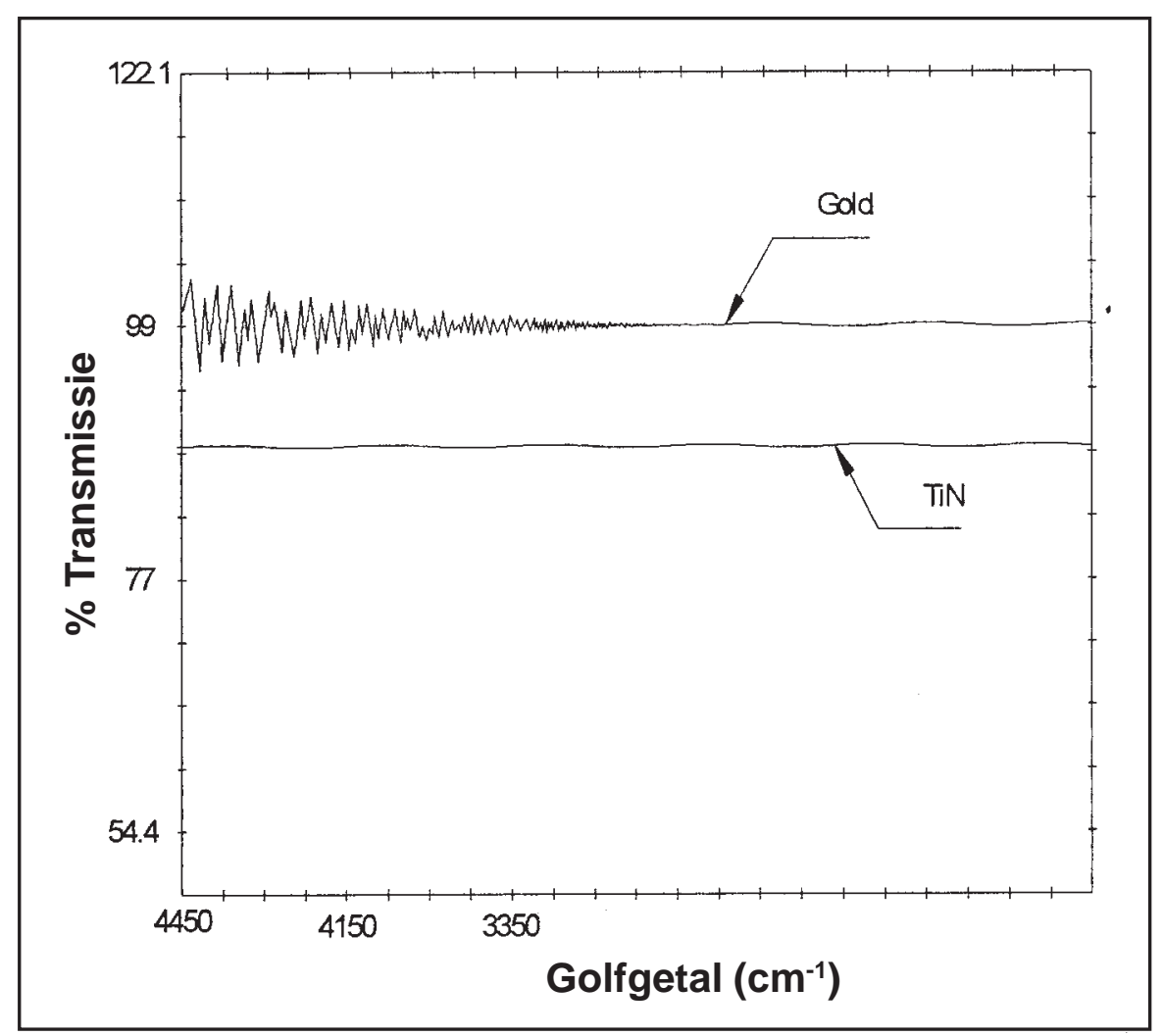

Figuur 2 Weerkaatsingsvermoë van onderskeidelik 'n goud- en 'n titaannitried-toetsspieël.

Tabel 1 Padlengte as 'n funksie van seinversterking

\begin{tabular}{|c|c|c|c|c|}
\hline PADLENGTE & \multicolumn{4}{|c|}{ SEINVERSTERKING VIR FOKUSPUNTSPIEёL } \\
\hline$(\mathrm{m})$ & $1.04 \mathrm{~m}$ & $1.82 \mathrm{~m}$ & $4.07 \mathrm{~m}$ & $5.00 \mathrm{~m}$ \\
\hline 1.25 & 7.44 & - & 11.52 & 7.83 \\
\hline 1.50 & 14.38 & 8.77 & 15.32 & 11.37 \\
\hline 1.75 & 17.88 & 9.14 & 14.43 & - \\
\hline 2.00 & 15.48 & 15.93 & - & - \\
\hline 2.25 & 10.22 & - & 12.43 & 9.97 \\
\hline 2.50 & - & 17.03 & - & - \\
\hline 3.00 & - & 8.88 & & - \\
\hline
\end{tabular}




\section{LITERATUURVERWYSINGS}

1. Smith, A.L., Wiley, A. (1979). Applied Infrared Spectroscopy (Wiley and Sons, New York) p.110 - 120.

2. Christian, G.D. (1986) Trace analysis: Spectroscopy methods for molecules, Chemical analysis 84, p5 - 110 .

3. Nicolet Technical Bulletin, Accuracy and Detection Limits in the ABO Analysis, 1005.

4. White, J.U. (1942) Long Optical Paths of Apeture, J. Opt. Soc. $A m, 32$ en 285, p. 285-288.

5. Brawe, E.H., Pannella, M.G. (1990) Circle Cell FTIR Analysis of Chemical Warfare Agents in Aqueous Solutions, Applied
Spectroscopy, 44, p. 1513-1520.

6. Nicolet Technical Bulletin, Automating the 8220 Gas Analyzer, 1006.

7. Burge, P.S., Hedge, A., Wilson, S., Harris, B., Robertson A.S. (1987) Sick Building Syndrome: A Study of 4373 office workers. Ann. Occup. Hyg., 31, p. 493-504.

8. Griffiths, P.R., De Haseth, J.A. Fourier Transform Infrared Spectrometry, J. Wiley and Sons, Vol 32, p. $220-521$.

9. Hannah, R.W. Infrared Applications in Air and Water Pollution a Bibliography, Perkin-Elmer Infrared Bulletin, 32.

10. Nicolet Technical Bulletin, Detection Limit Analysis of Benzene, Toluene and Trichloroethylene in Air, 1008. 